ISBN 978-81-933894-1-6

International Conference on Arts, Social Sciences, History and Interdisciplinary Studies

(ASSHIS-2017)

Kyoto (Japan) April 20-21, 2017

\title{
Consumer Behavior on Choosing Products and Services through Facebook
}

\author{
Dr. Tosaporn Mahamud, Mr. Panutat Latplee \\ Post graduate school of Business administration Kasembundit university, Bangkok \\ tosaporn.mah@kbu.ac.th
}

\begin{abstract}
The primary purpose of the study is to determine consumer behavior and level of consumer satisfaction on purchasing products and services through Facebook application. This study was the quantitative study with the samplings for this study were 400 people whom purchased products and services through Facebook application by using a questionnaire as a tool. The statistics used for data analysis were percentage, mean, standard deviation, $t$ test, one-way Anova, and multiple regression analysis.

From data analysis study can be concluded that most of 400 respondents were females, yielding a 59 percent response rate, age over 40 years old, yielding a 30.50 percent response rate, government services or state enterprise workers, yielding a 36.50 percent response rate, bachelor or equivalent degree graduated, yielding a 57.50 percent response rate, and average monthly income over 20,000 baht, yielding a 57.50 percent response rate. The overall picture of opinions of consumer behavior and level of consumer satisfaction on purchasing products and services through Facebook application were at high level at significant 0.05. The test of hypothesis revealed that factors of personal different, such as gender, age, level of education, and average income were not affected the factors of consumer satisfaction, such as, traveling and place to stay the most, yielding a 16.86 percent response rate, followed by 172 respondents were chosen technology products, yielding a 16.29 percent response rate, 138 respondents were chosen cosmetics products, yielding a 13.07 percent response rate, 134 respondents were chosen house supply products, yielding a 12.69 percent response rate, 138 respondents were chosen cosmetics products, yielding a 13.07 percent response rate, 108 respondents were chosen clothes products, yielding a 10.23 at significant level 0.05 .

Recommendations from the study were business owners should focus on products quality, prices, attractive webpage design, display prices of the items clearly, on time delivery, and discount prices offer during marketing promotion.
\end{abstract}

\section{Introduction}

In the era of social networks (social media), Facebook application is of social media which becomes main media for all ages. Zocial incorporated, reported on the growth rate of Facebook users of the world, such as Thailand, all Asian countries since year 2013-2015 revealed that in year 2013, Facebook users were 1.14 billion accounts, year 2014, Facebook users were 1.19 billion accounts which increased +3 percent, and year 2015, total of Facebook users were 1.39 billion accounts which increased +16.81 percent. Facebook users in Thailand are 35 million accounts ( growth $+34.62 \%$ ) which are number 3 rank of the world lower than Indonesia with 74 million Facebook users accounts (growth $+15.63 \%$ ), and Philippines with 44 million Facebook users accounts (growth $+22.22 \%$ ) researched from following website www.Zocialinc.com/blog/facebook_population_2015/In Thailand, divided into provinces and Bangkok are highest of Facebook users accounts of 20 million people, Chiang Mai with 0.96 million Facebook users accounts, Nakorn Ratchasima with 0.78 million Facebook user accounts. It is also likely to increase every year and this become one of the media for all business entrepreneurs are study to take the benefit of Facebook. 
Wikipedia (2555) specified that social media website, such as Facebook type of social network is a website service that can link between each party of its own social network through the Internet network. The user can create their own webpage that contains a picture, private information for communicating with friends or other users of the service via chat or messages. Users of the service can create or join groups that you are interested in, and can press like icon of their favorite pages. Facebook give freedom to users, business owner can generate revenue from it. You can create an unlimited number of photo albums and photos can be commented on Facebook, media marketers are interested this media because there are functions that help to sell, Facebook Fan Page, interacting with consumers via a system message (Facebook Messages) or in advertising with the fan page (Facebook Ads), multiple businesses or organizations, both domestic and foreign adoption for their primary media, using Facebook ads, and create the image of the business or organization to sell goods and services.

For a business or organization that wants to create the image on Facebook which is a tool that is convenient and fast way to reach consumers directly. No need to go through another media type that has high costs. To advertise with Facebook as one of the top online marketing channel. That can be clearly targeted and have reasonable cost. In order to make the Facebook users see their own products and services, there is also a report that can be read and understandable.

Advertising in Facebook called Facebook Ads are the ads that Facebook users of the service can see Facebook products or services of a company or organization by these ads. Results of users' access to (Reach) and the likes can be measured.

As for introduction mentioned above, researcher is interested in the subject of the social media guidelines in the distribution of goods and services and the results from the study can use as a guideline for the benefit of business owners as an investment option for the marketing promotion of their company.

\section{The Purpose of the Study}

1. To study consumer behavior on choosing products and services through Facebook.

2. To determine the level of consumer satisfaction on choosing products and services through Facebook.

TABLE 2.2: 7 Question with 6W1H to find the answer regarding consumer behavior

\begin{tabular}{|c|c|}
\hline Question (6 W 1 H ) & Answers \\
\hline 1. Who constitutes the market? & \begin{tabular}{|ll} 
Occupants \\
1. \\
2. & Deography \\
3. & Psychologhic \\
4. & Behavior \\
\end{tabular} \\
\hline 2. What does the market buy? & $\begin{array}{l}\text { Objects } \\
\text { 1. Products feature and services } \\
\text { 2. The composition of the product \& services }\end{array}$ \\
\hline 3. Why does the market buy? & 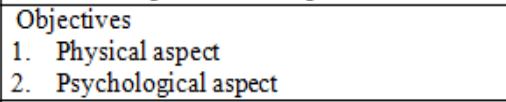 \\
\hline 4. When does the market buy? & $\begin{array}{l}\text { Occasions } \\
\text { 1. Any time of the month/day. } \\
\text { 2. Special occasion/festival }\end{array}$ \\
\hline 5. Where does the market buy? & \begin{tabular}{|ll|}
\multicolumn{2}{|l|}{ Outlets } \\
1. & Department stores \\
2. & Supermarket \\
3. & Convenient shops \\
4. & E-commerce \\
\end{tabular} \\
\hline 6. Whom participates in the buying? & $\begin{array}{l}\text { Organizations } \\
\text { 1. The originator. } \\
\text { 2. Persons of influence. } \\
\text { 3. Decision makers. } \\
\text { 4. The buyer. } \\
\text { 5. The user. }\end{array}$ \\
\hline 7. How does the market buy? & $\begin{array}{l}\text { Operations procedures in buying decision } \\
\text { 1. To recognize the problem. . } \\
\text { 2. Search for information. } \\
\text { 3. To evaluate altematives. } \\
\text { 4. Purchase decision. } \\
\end{array}$ \\
\hline
\end{tabular}




\section{The Results of the Study}

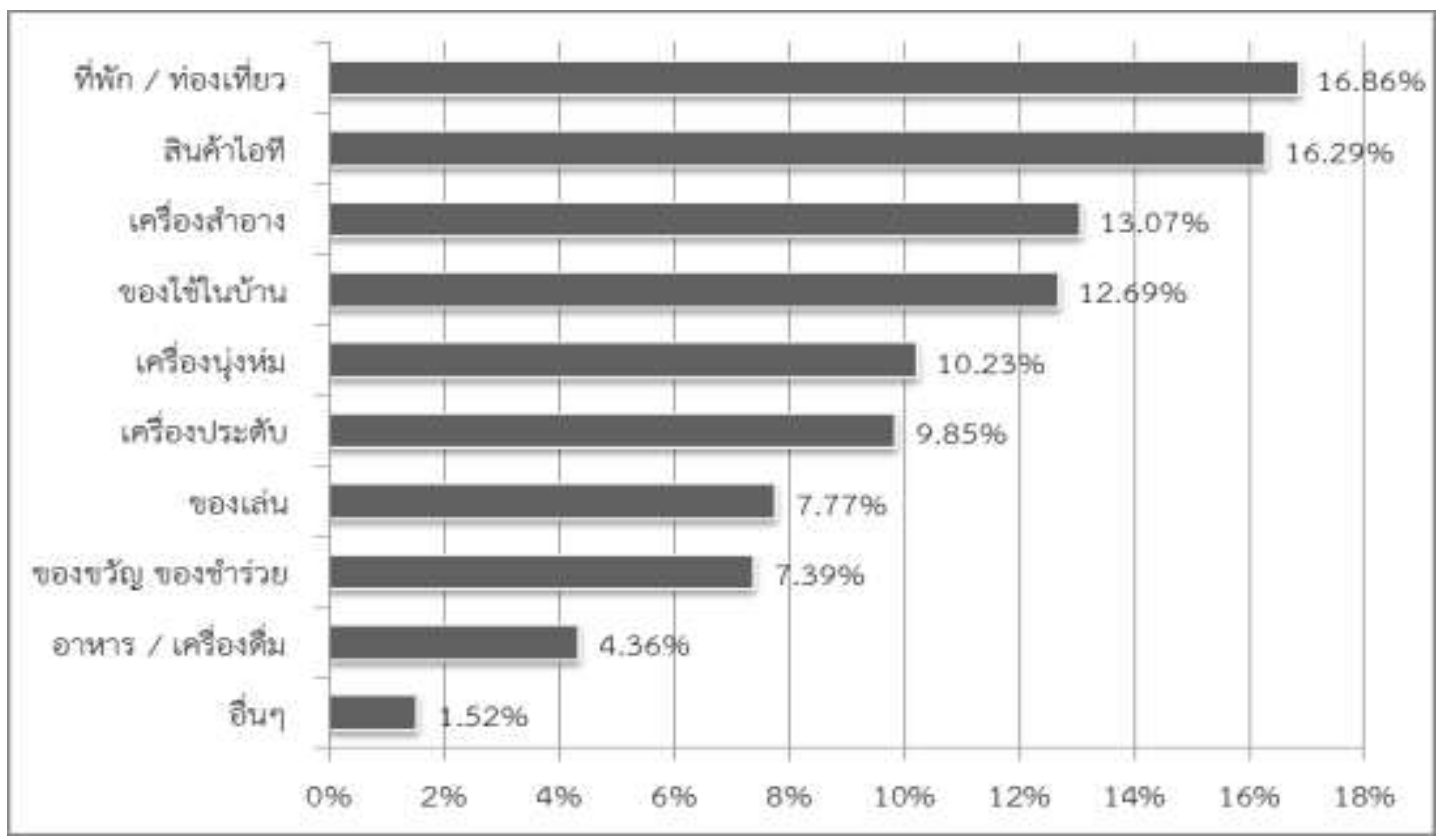

Fig. 4.2.8: Products and Services which Consumer Interested.

From figure 4.2.8 shows the overall picture of the opinions of 400 respondents, 178 respondents were chosen traveling and place to stay the most, yielding a 16.86 percent response rate, followed by 172 respondents were chosen technology products, yielding a 16.29 percent response rate, 138 respondents were chosen cosmetics products, yielding a 13.07 percent response rate, 134 respondents were chosen house supply products, yielding a 12.69 percent response rate, 138 respondents were chosen cosmetics products, yielding a 13.07 percent response rate, 108 respondents were chosen clothes products, yielding a 10.23 percent response rate, 104 respondents were chosen jewelry products, yielding a 9.85 percent response rate, 82 respondents were chosen games products, yielding a 7.77 percent response rate, 78 respondents were chosen gifts products, yielding a 7.39 percent response rate, 46 respondents were chosen foods and beverages products, yielding a 4.36 percent response rate, and 16 respondents were chosen other products, yielding a 1.52 percent response rate, respectively. 
TABLE 4.4.2.2: Multiple Comparison Of LSD Values Per The Level Of Consumer Satisfaction On Purchasing Products And Services Through Facebook Application Classify By Age.

\begin{tabular}{|c|c|c|c|c|c|c|c|}
\hline \multirow{2}{*}{ Age (I) } & \multirow{2}{*}{ Age $(J)$} & \multirow{2}{*}{$\begin{array}{c}\text { Mean } \\
\text { difference }\end{array}$} & \multirow{2}{*}{ Std. error } & \multirow{2}{*}{ Sig. } & \multicolumn{2}{|c|}{$95 \%$ confidence interval } & \multirow{2}{*}{ results } \\
\hline & & & & & $\begin{array}{l}\text { Lower } \\
\text { bound }\end{array}$ & $\begin{array}{l}\text { Upper } \\
\text { bound }\end{array}$ & \\
\hline \multirow[t]{5}{*}{$15-19$ yrs. } & $20-24$ & -.05455 & .18899 & .773 & -.4261 & .3170 & $\begin{array}{l}\text { No } \\
\text { different }\end{array}$ \\
\hline & $25-29$ & -.17455 & .17225 & .312 & -.5132 & .1641 & $\begin{array}{l}\text { No } \\
\text { different }\end{array}$ \\
\hline & $30-34$ & -.16608 & .15800 & .294 & -.4767 & .1445 & $\begin{array}{l}\text { No } \\
\text { different }\end{array}$ \\
\hline & $35-40$ & .04545 & .16402 & .782 & -.2770 & .3679 & $\begin{array}{l}\text { No } \\
\text { different }\end{array}$ \\
\hline & $40 \&$ over & .26677 & .15595 & .088 & -.0398 & .5734 & $\begin{array}{l}\text { No } \\
\text { different }\end{array}$ \\
\hline \multirow[t]{5}{*}{$20-24$ yrs. } & $15-19$ & .05455 & .18899 & .773 & -.3170 & .4261 & $\begin{array}{l}\text { No } \\
\text { different }\end{array}$ \\
\hline & $25-29$ & -.12000 & .15549 & .441 & -.4257 & .1857 & $\begin{array}{l}\text { No } \\
\text { different }\end{array}$ \\
\hline & $30-34$ & -.11154 & .13953 & .425 & -.3859 & .1628 & $\begin{array}{l}\text { No } \\
\text { different }\end{array}$ \\
\hline & $35-40$ & .10000 & .14631 & .495 & -.1876 & .3876 & $\begin{array}{l}\text { No } \\
\text { different }\end{array}$ \\
\hline & $40 \&$ over & $.32131^{*}$ & .13721 & .020 & .0516 & .5911 & Different \\
\hline \multirow[t]{5}{*}{$25-29$ yrs. } & $15-19$ & .17455 & .17225 & .312 & -.1641 & .5132 & $\begin{array}{l}\text { No } \\
\text { different }\end{array}$ \\
\hline & $20-24$ & .12000 & .15549 & .441 & -.1857 & .4257 & $\begin{array}{l}\text { No } \\
\text { different }\end{array}$ \\
\hline & $30-34$ & .00846 & .11587 & .942 & -.2193 & .2363 & $\begin{array}{l}\text { No } \\
\text { different }\end{array}$ \\
\hline & $35-40$ & .22000 & .12394 & .077 & -.0237 & .4637 & $\begin{array}{l}\text { No } \\
\text { different }\end{array}$ \\
\hline & $40 \&$ over & $.44131^{*}$ & .11306 & .000 & .2190 & .6636 & Different \\
\hline \multirow[t]{5}{*}{ 30-34 yrs. } & $15-19$ & .16608 & .15800 & .294 & -.1445 & .4767 & $\begin{array}{l}\text { No } \\
\text { different }\end{array}$ \\
\hline & $20-24$ & .11154 & .13953 & .425 & -.1628 & .3859 & $\begin{array}{l}\text { No } \\
\text { different }\end{array}$ \\
\hline & $25-29$ & -.00846 & .11587 & .942 & -.2363 & .2193 & $\begin{array}{l}\text { No } \\
\text { different }\end{array}$ \\
\hline & $35-40$ & $.21154^{*}$ & .10322 & .041 & .0086 & .4145 & Different \\
\hline & $40 \&$ over & $.43285^{*}$ & .08986 & .000 & .2562 & .6095 & Different \\
\hline \multirow[t]{5}{*}{$35-40$ yrs. } & $15-19$ & -.04545 & .16402 & .782 & -.3679 & .2770 & $\begin{array}{l}\text { No } \\
\text { different }\end{array}$ \\
\hline & $20-24$ & -.10000 & .14631 & .495 & -.3876 & .1876 & $\begin{array}{l}\text { No } \\
\text { different }\end{array}$ \\
\hline & $25-29$ & -.22000 & .12394 & .077 & -.4637 & .0237 & $\begin{array}{l}\text { No } \\
\text { different }\end{array}$ \\
\hline & $30-34$ & $-.21154^{*}$ & .10322 & .041 & -.4145 & -.0086 & Different \\
\hline & $40 \&$ over & $.22131^{*}$ & .10006 & .028 & .0246 & .4180 & Different \\
\hline \multirow[t]{5}{*}{40 or over } & $15-19$ & -.26677 & .15595 & .088 & -.5734 & .0398 & Different \\
\hline & $20-24$ & $-.32131^{*}$ & .13721 & .020 & -.5911 & -.0516 & Different \\
\hline & $25-29$ & $-.44131^{*}$ & .11306 & .000 & -.6636 & -.2190 & Different \\
\hline & $30-34$ & $-.43285^{*}$ & .08986 & .000 & -.6095 & -.2562 & Different \\
\hline & $35-40$ & $-.22131^{*}$ & .10006 & .028 & -.4180 & -.0246 & Different \\
\hline
\end{tabular}

*Significant level 0.05 


\section{Summary of the Study}

The purpose of the study is to determine consumer behavior and level of consumer satisfaction on purchasing products and services through Facebook application. This study was the quantitative study with the samplings for this study was 400 people whom purchased products and services through Facebook application by using a questionnaire as a tool. The statistics used for data analysis were percentage, mean, standard deviation, t-test, one-way Anova, and multiple regression analysis.

From data analysis study can be concluded that most of 400 respondents were females, yielding a 59 percent response rate, age over 40 years old, yielding a 30.50 percent response rate, government services or state enterprise workers, yielding a 36.50 percent response rate, bachelor or equivalent degree graduated, yielding a 57.50 percent response rate, and average monthly income over 20,000 baht, yielding a 57.50 percent response rate.

The overall picture of opinions of consumer behavior and level of consumer satisfaction on purchasing products and services through Facebook application were at high level at significant 0.05 .

\section{Reference}

[1] Siriwan Serirat. (2001). Consumer Behavior. Bangkok: Wisitwattana.

[2] Siriwan Serirat and Amornsak Boonrueng. (2003). Modern Marketing Management. Bangkok: Diamond in business world.

[3] Siriwan Serirat et al. (1998). Business Research. Bangkok: Diamond in business world.

[4] Thanin Trairak. (2011). Marketing Factors that have Influences on Customers in Bangkok's Purchasing

[5] Decision for Products in Man-U Shop. Independent study.

[6] Marketing Major. Faculty of Business Administration. Rajamangala University of Technology Thanyaburi.

[7] Thongchai Santiwong. (1997). Consumer Behavior. Bangkok: Thaiwattanapanich 